\title{
Jan Fabian Woźniak* \\ Kulturowe uwarunkowania innowacyjnego wizerunku organizacji na przykładzie firmy Apple Inc.
}

Streszczenie: Celem rozdziału jest dokonanie analizy innowacyjnego wizerunku firmy Apple Inc. i pokazanie jaki wpływ na jego kreowanie miała tożsamość organizacji, kultura korporacyjna oraz przywództwo Steve'a Jobsa. W opracowaniu opisane zostały również różnice i podobieństwa między amerykańską kulturą narodową i kulturą organizacyjną firmy Apple Inc.

Słowa kluczowe: kultura organizacyjna, kultura korporacyjna, przywództwo, wizerunek, innowacja, Apple Inc.

\section{Wstęp}

W warunkach wzmożonej konkurencji rynkowej oraz krótkich cykli produkcyjnych, przedsiębiorstwa w walce o klienta poszukują źródeł korzystnego wizerunku. W przemyśle wysokiej technologii biznes walczy o image innowatora, który przyciągnie nawet najbardziej wymagających klientów ponieważ pozwala wierzyć, że produkt takiego producenta gwarantuje jakość i pionierstwo. Wizerunek jako pochodna tożsamości organizacji w dużej mierze wynika z zakresu, w jakim organizacja uważa się za innowacyjną. Tylko wtedy wykształci ona autentyczny wizerunek pioniera kiedy świadomie zidentyfikuje swoje wartości i wyeksponuje właściwe dla nich atrybuty.

Wartości są nierozerwalnie związane z kulturą organizacyjną, w której badacze i praktycy biznesu upatrują przyczyn sukcesu lub porażki przedsiębiorstwa. Stanowi ona rdzeń organizacji, determinując metody postępowania, określając pożądane i niedozwolone zachowania oraz formułując co dla grupy jest najważniejsze. Istotny udział w kreowaniu kultury

* Wydział Zarządzania, Uniwersytet Łódzki. 
biorą fundatorzy i liderzy organizacji, którzy zaszczepiają w niej własne wartości, wierzenia i zasady. Wpływ liderów na kulturę jest tym silniejszy im więcej wiary w ich wizję pokładają podwładni, ale zależy również od stopnia, w jakim istniejąca kultura dopuszcza silną pozycję przywódcy.

Celem mniejszego rozdziału jest przybliżenie kultury organizacyjnej ze szczególnym uwzględnieniem przywództwa jako czynnika wpływającego na tożsamość i determinującego innowacyjny wizerunek organizacji. Dokonano opisu kultury korporacyjnej firmy Apple Inc. i porównano $\mathrm{z}$ amerykańską kulturą narodową. Sportretowano wizjonerskie przywództwo Steve'a Jobsa, jego wpływ na wartości i wizerunek przedsiębiorstwa oraz wskazano jego konstruktywne i destrukcyjne aspekty.

\section{Wpływ kultury organizacyjnej i przywództwa na wizerunek}

O sukcesie rynkowym przedsiębiorstwa, w czasach szczególnie silnej konkurencji rynkowej, globalizacji, ułatwionego dostępu do dóbr i przyspieszonego cyklu życia produktu, decydują nie tylko obiektywne parametry obejmujące jakość produktu, cenę, czy efektywność produkcji, ale również wizerunek podmiotu, który jest wybitnie subiektywną impresją klienta.

Właściwy wizerunek organizacji niesie szereg zalet dla przedsiębiorstwa. W czasach ułatwionego dostępu do alternatywnych wyrobów oraz powszechnej jakości czynnikiem istotnie wpływającym na decyzje zakupowe klientów stała się cena. Przy tym porównywanie cen przy pomocy internetu stało się szybkie i proste. W takich warunkach rynkowej konkurencji oferta przedsiębiorstwa musi posiadać wyróżniki, które nadadzą jej status wyjątkowej, innej od pozostałych. To nie tylko pozwala podnieść sprzedaż, ale również zwiększyć marżę. Szczególny image marki lub produktu może nakłonić klienta do jego zakupu nawet pomimo wyższej ceny [Altkorn, 2004: 26].

Zysk przedsiębiorstwa zwiększa nie tylko wyższa marża i lepsza sprzedaż, ale także zmniejszenie wydatków związanych z działalnością firmy. „Dostawcy, banki, dystrybutorzy skłonni są obniżyć swoje ceny dla renomowanych odbiorców, ponieważ kooperacja z nimi jest bardziej stabilna, a także dlatego, iż taka współpraca poprawia własną reputację" [Ibidem: 28]. Efektem dobrego wizerunku organizacji jest także przywiązanie klientów. Rzesze lojalnych klientów stabilizują działalność spółki, która 
jest w mniejszym stopniu uzależniona od koniunktury gospodarczej i wahań popytu.

Zrozumienie i pielęgnowanie przez organizację swojej tożsamości mającej źródło w wartościach ma na celu wykreowanie wizerunku postrzeganego przez otoczenie za wiarygodny i zgodny z faktycznym funkcjonowaniem organizacji. Wartości w organizacji są pochodną i wypadkową poglądów fundatorów i członków organizacji, kultury organizacyjnej oraz kultury państwa, w którym funkcjonuje przedsiębiorstwo.

Próby zdefiniowania kultury organizacyjnej są równie liczne co wysiłki określenia, czym jest kultura w ogóle. Nie istnieje spójna definicja pojęcia, a spory dotyczące tego czym jest kultura organizacyjna są fundamentalne. Już sam termin u wielu badaczy zawiera różnice semantyczne, zjawisko to nazywają kultura organizacyjna (np. C. Sikorski, G. Hofstede), kultura w organizacji (np. L. Zbiegień-Maciąg), kultura organizacji czy kultura korporacyjna [Zbiegień-Maciąg, 2005: 10].

Różnice znaczeniowe wynikają z odmiennych poglądów. Niektóry autorzy odrzucają kulturę w organizacji, twierdzą, że sama organizacja jest kulturą. Powszechniejszy wydaje się jednak pogląd, że kultura występuje w organizacji, a swoje źródła ma w wartościach, normach, wierzeniach, wskazówkach i zasadach formułowanych przez fundatorów organizacji oraz jej liderów. Nadzwyczaj krótką jej definicję przedstawili T. Deal i A. Kennedy, stwierdzając, że ,kultura organizacji to sposób w jaki my to tutaj robimy" [Bjerke, 2004: 24].

Clyde Kluckhohn oraz William Kelly opisali kulturę jako „wszystkie historycznie ukształtowane wzorce życia, jawne i ukryte, racjonalne i irracjonalne, które istnieją $\mathrm{w}$ danym czasie jako potencjalne wskazówki zachowania człowieka" [Ibidem: 15].

Kultura organizacyjna ma istotne znaczenie dla organizacji, jej właścicieli i interesariuszy. Oparta na właściwych wartościach i dopasowana do potrzeb organizacji pomaga realizować cele biznesowe. E. Schein charakteryzuje kulturę jako „zespół rozsądnych reguł postępowania, odkrytych, ustanowionych i rozwiniętych przez grupę, służących do zmagania się z problemem wewnętrznej integracji i zewnętrznym dostosowaniem, które dzięki wystarczająco dobremu działaniu wytyczają nowym członkom sposób myślenia i odczuwania w aspekcie wspomnianych problemów" [Zbiegień-Maciąg, 2005: 16] już w definicji zwracając uwagę na jej funkcje.

Holenderski badacz kultury G. Hofstede, którego zainteresowały różnice kulturowe, przeanalizował dane zebrane wśród pracowników IBM z czterdziestu krajów świata. Na ich podstawie stworzył model klasyfikacji kultury organizacyjnej w ujęciu narodowym. Zaproponował najpierw cztery, a później pięć [Hofstede, 2007: 41] wymiarów opisujących kulturę 
organizacyjną (narodową): dystans władzy, indywidualizm i kolektywizm, męskość i kobiecość, unikanie niepewności, orientacja krótkoterminowa i długoterminowa [Zbiegień-Maciąg, 2005: 70].

Kultura organizacyjna opisuje zatem stosunek członków organizacji do otoczenia. Różne kultury znamionują różne podejście do ryzyka, pracowników i współpracowników, wpływają na strukturę organizacji, stawiają na piedestale różne wartości, nobilitują inne postawy i wskazują różne pożądane zachowania. $Z$ tego wynika podejście członków organizacji do klienta, produktu, jakości, jak również to determinuje atrybuty komunikowane przez przedsiębiorstwo otoczeniu. Kultura organizacyjna rzutuje na wartości i postawy całej organizacji, a zatem również na styl zarządzania. Wysokość wskaźnika dystansu władzy w organizacji determinuje autorament tej władzy, stosunek pracowników do zwierzchników i sposób sprawowania zwierzchności. Szczególnie istotne z punktu widzenia długoterminowych dążeń przedsiębiorstwa jest przywództwo, które gwarantuje wizję i przygotowanie organizacji na przyszłość.

Wśród wszystkich prób kreowania korzystnego wizerunku, szczególnie popularny jest dziś image innowatora. Zwłaszcza w określonych branżach, jak przemysł wysokiej technologii, zapewnia lojalność klientów oraz ich gotowość na zakup potencjalnie niezweryfikowanych jeszcze produktów. W konsekwencji decyduje o sukcesie przedsiębiorstwa.

Według Ralpha Stogdilla przywództwo jest jednocześnie procesem i właściwością [Stogdill, 1974: 83]. W pierwszym znaczeniu jest umiejętnością ukierunkowania w sposób niewymuszony działań członków organizacji w celu osiągnięcia grupowych dążeń. W drugim są to cechy osobowości, które pozwalają, z sukcesem, wywierać taki wpływ.

Badacze zauważyli, że zachowania przywódcze charakteryzują się różną skutecznością $\mathrm{w}$ odmiennych sytuacjach, podjęto zatem próby znalezienia zależności między uwarunkowaniami a efektywnością stylów przywództwa. Podejście sytuacyjne wykształciło wiele istotnych koncepcji dopasowania stylu przywództwa do pewnych okoliczności. Szczególnie znany jest model Vrooma-Yettona-Yego, który określa pięć stylów podejmowania decyzji o różnym stopniu uczestnictwa grupy w procesie decyzyjnym.

Model Vrooma-Yettona-Yego zakłada, że „najlepszym miernikiem skuteczności decyzji jest jej jakość i akceptacja przez pracowników. Jakość decyzji to jej obiektywny wpływ na wyniki działania. Akceptacja decyzji to zakres, w jakim pracownicy akceptują decyzję i angażują się w jej wykonanie" [Griffin, 2004: 572]. 


\section{Metodyka badań}

Głównym celem badań było zbadanie jak kultura organizacyjna oraz charakter i wizjonerstwo Steve'a Jobsa wpływały na wizerunek firmy Apple Inc.

Do celów szczegółowych należało:

- zbadanie, jakie atrybuty Apple Inc. komunikuje klientom, interesariuszom oraz własnym pracownikom,

- pokazanie zależności i różnic między modelem amerykańskiej kultury organizacyjnej a kulturą organizacyjną Apple Inc.

W rozdziale zastosowano analizę źródeł wtórnych, nazywaną również analizą źródeł zastanych lub z angielskiego metodą desk research, polegającą na wyszukiwaniu i przetwarzaniu istniejących danych, w szczególności literatury i danych statystycznych. Porównano teoretyczne koncepty kultury organizacyjnej, przywództwa oraz wizerunku, szczególnie pochodzące z opracowań G. Hofstede [2007], C. Sikorskiego [2006] i J. Altkorna [2004] z dysertacjami na temat amerykańskiej kultury B. Bjerke [2004] oraz kultury organizacyjnej i przywództwa w Apple Inc. opracowanych przez W. Isaacsona [2011], C. Gallo [2011] oraz L. Kahneya [2010]. W celu podkreślenia roli wizerunku wykorzystano również dane statystyczne i finansowe.

\section{Wyniki badań}

\section{Wizerunek}

$\mathrm{Z}$ wielu powodów firma Apple Inc. jest interesującym przedmiotem rozważań nad kulturą organizacyjną oraz przywództwem w kontekście wizerunku marki. Apple bardzo starannie dba o wizerunek i pielęgnuje własną tożsamość. Najlepszą egzemplifikacją zrozumienia przez Apple własnej natury są dwie słynne reklamy firmy.

W 1984 roku, tuż przed odejściem Steve'a Jobsa, Apple we współpracy z agencją reklamową Chiat/Day stworzyła reklamę nagrodzoną trzydziestoma pięcioma nagrodami, w tym Grand Prix w Cannes [Griffin, 2004: 109]. Spot został wyreżyserowany przez Ridleya Scotta i w niczym nie przypominał innych reklam z tamtego okresu. Krótkometrażowa produkcja przedstawiała totalitarną, orwellowską przyszłość, która zmusza ubezwłasnowolnione masy do wysłuchiwania wrogiej propagandy z ust Wielkiego Brata pojawiającego się na ogromnych rozmiarów ekranie. W czasie tego pełnego nienawiści i zniewolenia seansu do sali 
wbiega, uciekająca przed totalitarną policją, wysportowana kobieta, która powziąwszy zamach, rozbija telebim i przerywa propagandowy monolog.

Spot wyemitowano 22 stycznia 1984 roku, w przerwie finałowej rozgrywki mistrzostw futbolu amerykańskiego. Dzięki temu reklamę obejrzało 96 milionów ludzi jednocześnie [Isaacson, 2011: 214]. W trwającej 60 sekund reklamie ani przez moment nie pojawił się żaden komputer. Przekaz okazał się jednak klarowny, komputer Apple stawia odpór konformizmowi i masowości produktów potężnych korporacji. W ostatnich sekundach spotu lektor ogłosił: „24 stycznia Apple Computer zaprezentuje Macintosha. I zobaczycie, dlaczego rok 1984 nie będzie taki jak Rok 1984" (thumaczenie: P. Bieliński i M. Strąkow) [Ibidem].

Gdy w 1996 roku Steve Jobs powrócił do Apple, stwierdził, że spółka straciła nie tylko udziały w rynku, ale również siłę wyrazu własnej tożsamości. Dlatego zwrócił się do TBWA/Chiat/Day z prośbą o stworzenie nowej kampanii wizerunkowej. „Jobs i Clow ${ }^{1}$ zgadzali się, że Apple to jedna z najsilniejszych marek na świecie - prawdopodobnie jedna z pięciu czołowych, jeśli brać pod uwagę skuteczność, z jaką odwołują się do emocji - trzeba było jednak przypomnieć ludziom, co ją wyróżnia. (...) Kampania skierowana była nie tylko do potencjalnych klientów, ale także do pracowników Apple" [Ibidem: 402].

Efektem współpracy Apple i TBWA/Chiat/Day było powstanie spotu reklamowego o wymownym tytule Think different. Reklama była bardzo prosta $\mathrm{w}$ swojej formie, przedstawiała czarno-białe niepodpisane fotografie słynnych artystów, naukowców, wynalazców, sportowców m.in. Alberta Einsteina, Boba Dylana, Martina Luthera Kinga, Richarda Bransona, Johna Lennona, Thomasa Edisona, Muhammada Alego, Mahatmy Gandhiego, Alfreda Hitchcocka i Pablo Picasso. Fotografiom towarzyszył głos aktora Richarda Dreyfussa składającego hołd ,szaleńcom zmieniającym świat”: „Za tych, co szaleni. Za odmieńców. Buntowników. Awanturników. Niedopasowanych. Za tych, co patrzą na świat inaczej. Oni nie lubią zasad. Nie szanują status quo. Można ich cytować, można się z nimi nie zgadzać; można ich wysławiać, można ich zniesławiać. Ale jednego nie można zrobić - nie można ich ignorować. Bo to oni zmieniają świat. Popychają ludzkość do przodu. I choć niektórzy mogą widzieć w nich szaleńców, my dostrzegamy w nich geniusz. Ponieważ to ludzie wystarczająco szaleni, by sądzić, że mogą zmienić świat... są tymi, którzy go zmieniają" [Ibidem: 403].

1 Wówczas dyrektorem kreatywnym agencji TBWA/Chiat/Day był Lee Clow. 
Podobnie jak w reklamie z 1984 roku i tym razem w spocie nie pojawia się żaden produkt. „Firma potrzebowała publicznej deklaracji swoich wartości i celów - zarówno dla swoich pracowników, jak i klientów. Kampania „Think different” celebrowała jej cnoty: kreatywność, wyjątkowość i ambicję" [Kahney, 2010: 110].

Działania Apple wpisują się w trend opisywany przez J. Altkorna - wiele współczesnych firm odchodzi od promocji produktów i ich cech użytkowych na rzecz komunikowania związanych z nimi i marką odczuć. U dzisiejszego klienta wzmaga się silna potrzeba dowiedzenia swojego indywidualizmu, kupuje on zatem produkty, które pozwalają mu wyróżnić się i określić przynależność. „Nie tylko reklama, ale i dystrybucja zmierzają do przekonania, iż produkt jest elementem świadczącym o przynależności do wspólnoty uprawiających pewien styl życia" [Altkorn, 2004: 22].

Tabela 1. Najwartościowsze marki na świecie

\begin{tabular}{|c|c|c|c|}
\hline Lp. & Marka & Wartość marki (w mld USD) & Data powstania \\
\hline 1. & Apple & 170,0 & 1976 \\
\hline 2. & Google & 101,8 & 1998 \\
\hline 3. & Microsoft & 87,0 & 1975 \\
\hline 4. & Facebook & 73,5 & 2004 \\
\hline 5. & Coca-Cola & 56,4 & 1892 \\
\hline 6. & Amazon & 54,1 & 1994 \\
\hline 7. & Disney & 43,9 & 1923 \\
\hline 8. & Toyota & 41,1 & 1937 \\
\hline 9. & McDonald's & 40,3 & $1940(1955)^{\mathrm{a}}$ \\
\hline 10. & Samsung & 38,2 & 1938 \\
\hline 17. & Mercedes-Benz & 29,2 & 1881 \\
\hline 25. & Marlboro & 24,1 & 1924 \\
\hline 39. & Ford & 13,8 & 1903 \\
\hline
\end{tabular}

a Przedsiębiorstwo zostało założone przez braci McDonald w 1940 roku, ale dopiero w 1955 roku Ray Kroc stworzył spółkę McDonald’s Systems, Inc.

Źródło: opracowanie własne na podstawie: Forbes, The World's Most Valuable Brands, https://www.forbes.com/powerful-brands/list/ (dostęp: 06.04.2018).

Wizerunek, który sukcesywnie buduje Apple, staje się stymulantem lojalności klientów. Według badania przeprowadzonego w 2017 roku przez Morgan Stanley \& Co. aż 92\% użytkowników iPhone'a deklaruje, że w ciągu kolejnych 12 miesięcy zdecyduje się na nowe urządzenie firmy Apple, podczas gdy podobną lojalność zdeklarowało tylko 77\% klientów Samsunga i zaledwie 59\% użytkowników LG [Hernandez, 2017]. 
Wyjątkowy wizerunek firmy znajduje swoje odzwierciedlenie w wartości marki. W 2017 roku magazyn Forbes umieścił Apple na szczycie swojej listy najsilniejszych marek na świecie (tabela 1). Spółka pokonała w rankingu kultowe marki takie jak Coca-Cola, Disney, McDonald's, Mercedes Benz, Ford czy Marlboro. Wartość marki Apple, Forbes wycenił na 170 miliardów dolarów [Forbes, The World's...].

Wycena ma swoje uzasadnienie. Firmę wspierają miliony lojalnych klientów, którzy regularnie kupują jej produkty. W 2017 roku spółka Apple odnotowała przeszło 229 miliardów dolarów przychodu, wygenerowała 48 miliardów dolarów zysku [Wyniki godne pozazdroszczenia. Ale Apple dopiero idzie na rekord, 2017] i po raz kolejny pobiła swoje finansowe rekordy.

\section{Przywództwo}

Pomimo tego, że przez przeszło dekadę, na przełomie lat osiemdziesiątych i dziewięćdziesiątych, Steve Jobs znajdował się poza Apple, przywództwo w tej spółce silnie kojarzone jest z jego osobą. Nic w tym dziwnego, firmował słynne produkty jak Mac, iPod i iPhone, przez wiele lat pełnił funkcję dyrektora generalnego, wyprowadził firmę z głębokiego kryzysu wizerunkowego i finansowego, a przede wszystkim był jej współzałożycielem oraz kreatorem jej korporacyjnej kultury oraz filozofii.

Odwołując się do definicji przywództwa R. Stogdilla [patrz podrozdział: Wptyw kultury organizacyjnej i przywództwa na wizerunek] S. Jobs spełniał kryteria przywództwa w sensie właściwości. Cechował się dużymi pokładami charyzmy, które uczyniły z niego ikonę popkultury, bohatera mediów i niedościgniony wzór dla przedsiębiorców. W. Isaacson pisze, że ludzie z otoczenia Jobsa nazywali jego umiejętności przekonywania innych oraz forsowania własnej wizji ,polem zniekształcania rzeczywistości” [Isaacson, 2011: 161], a J. Young stwierdza, że Jobs ,ma wiarę handlowca w tworzony przez siebie produkt, żarliwość nawiedzonego kaznodziei, skupia się na celu z gorliwością fanatyka i dąży do sukcesu z determinacją dziecka z biednej rodziny” [Gallo, 2011: 76].

Niezwykłej charyzmie Jobsa towarzyszyło zawsze bardzo silne przekonanie o własnej wartości i nieomylności. Był pewny swoich kompetencji i odrzucał potrzebę uznania społecznego, doskonale jednak rozumiał, że niektórzy ludzie są złaknieni pochlebstw, co bez skrupułów potrafił wykorzystywać by osiągać swoje cele. W. Isaacson spostrzega, że u podstaw ideologii Jobsa, leżało „głębokie i niezachwiane przekonanie, że zasady go nie dotyczą. Miał poczucie wyjątkowości: 
tego, że jest wybrańcem i oświeconym. (...) Jobs nigdy nie studiował Nietzschego, ale koncepcje tego filozofa dotyczące siły woli i wyjątkowości Nadczłowieka przychodziły mu naturalnie. (...) Nawet w małych, codziennych aktach buntu, takich jak niezakładanie tablic rejestracyjnych w samochodzie i parkowanie na miejscach dla niepełnosprawnych, zachowywał się jakby nie dotyczyły go powszechnie obowiązujące zasady" [Ibidem: 163].

Postawa Jobsa przypomina opisany przez C.G. Junga archetyp trickstera skłonnego podważać istniejący porządek i negować autorytety. Trickster jest bohaterem, który łączy w sobie skrajne cechy, pozytywne i negatywne. Łamie obowiązujące reguły, może się wydawać odstręczający, ale jego działania dają pozytywne rezultaty. Tricksterowi brakuje etykiety, manier, potrafi być do bólu szczery, ale i nieszczery gdy pozwala mu to osiągnąć cel. Jednocześnie cechują go piekielny spryt i inteligencja. W kontekście wizerunku innowatora jakim cieszył się Jobs, ciekawa wydaje się także mitologiczna sylwetka trickstera: ,W mitologii, etnologii i religioznawstwie trickster to bóg, duch, człowiek lub zwierzę antropomorficzne, które działa wbrew ustalonemu porządkowi - nie jest wprawdzie w stanie zburzyć go zupełnie, ale może w poważny sposób naruszyć jego doskonałość. Jawi się on także jako (...) twórca i nauczyciel sztuk, a więc i patron twórczości" [Struzik, 2013: 243].

Jobsa charakteryzowała także przemożna potrzeba sprawowania ciągłej kontroli nad najdrobniejszymi aspektami produktów i funkcjonowania firmy. Pewnego dnia nakazał by wszystkie gazowane napoje w firmowych lodówkach zamienić na ekologiczne soki pomarańczowe i marchwiowe [Isaacson, 2011: 162]. Potrzeba kontroli objawia się także w strukturze systemów operacyjnych, które w przypadku Apple są bardziej zamknięte niż to ma miejsce w przypadku konkurencyjnych platform. Jobs był prawdopodobnie jedynym CEO (ang. chief executive officer - dyrektor generalny) korporacji tych rozmiarów, który nadzorował każdy produkt swojej firmy, od systemu operacyjnego po materiał, z którego wykonana zostaje obudowa [Ibidem: 173].

Charyzma i nadane sobie samemu prawo do odrzucania reguł, dały Jobsowi nie tylko władzę nad ludźmi, ale również moc wpływania na kulturę firmy. Wartości, na których opierają się działania Apple to wartości, którymi kierował się Jobs.

Skutki jego silnego, charyzmatycznego, ale nie pozbawionego wizji przywództwa były zarówno korzystne jak i destrukcyjne. Powodował, że jego zespół osiągał więcej niż wydawało się możliwe. „Pole zniekształcenia rzeczywistości ma wielką moc, pozwalało Jobsowi inspirować swój zespół do zmiany biegu historii przemysłu komputerowego przy wykorzystaniu ułamka zasobów Xeroxa czy IBM-u" [Ibidem: 162-163]. 
Istotne jest również, że pracownicy Apple realizowali swoje zadania z pasją i podzielając zamiłowania Jobsa. Ciemną stroną jego charyzmy było przede wszystkim uniemożliwienie rozwoju proinnowacyjnej kultury organizacyjnej. Autokratyczne decyzje nie tylko uśmiercały kreatywne inicjatywy podwładnych, ale również doprowadziły $\mathrm{u}$ wielu do wypalenia zawodowego oraz raniły ludzkie uczucia. Nadmiar wizji kładł się również cieniem na zarządzaniu firmą. $Z$ powodu ciągłych interwencji Jobsa przekraczano terminy i budżety [Ibidem: 167$]$.

$\mathrm{Z}$ punktu widzenia wizerunku przedsiębiorstwa, charyzmatyczne przywództwo Jobsa implikowało bardzo silne powiązanie spółki z jego osobą. W konsekwencji, jego odejście w 1985 roku, powrót w roku 1996, czy informacje dotyczące choroby i śmierci, wpływały na giełdowy kurs Apple, prognozy i opinie ekspertów, a także powszechnie utożsamiano, słusznie zresztą, innowacyjność organizacji z jego wizjonerstwem. Jobs rozumiał jednak, jak ważny jest wizerunek. Wykorzystując swoją pozycję i umiejętność wywierania silnego wpływu, forsował rozwiązania marketingowe i produktowe wpisujące się $\mathrm{w}$ misternie zaplanowany, skonstruowany i pielęgnowany wizerunek.

Steve Jobs komunikował otoczeniu wizerunek Apple powiązany z nowatorstwem, perfekcjonizmem i elitaryzmem. Dawały temu wyraz każda premiera, konferencja oraz kampania marketingowa, które przybierały formę publicznej deklaracji wartości.

Jobs wielokrotnie podkreślał, że produkty Apple kierowane są do wybranej, elitarnej grupy klientów. Wyrażał to, tworząc kampanię Think different, a także podczas swojego wystąpienia na konferencji Macworld 7 sierpnia 1997 roku gdzie stwierdził: „Uważam, że nadal trzeba myśleć inaczej, żeby kupić komputer Apple. Sądzę, że osoby, które go kupują, faktycznie myślą inaczej. Są twórczymi duchami tego świata. Są ludźmi, którym nie zależy po prostu na wykonania zadania - oni chcą zmieniać świat" [Gallo, 2011: 123].

CEO dbał o konsekwentne komunikowanie atrybutów organizacji na każdym etapie kontaktu z marką i jej produktem. Gdy klient przyciągnięty reklamą pojawiał się w jednym z salonów firmowych, był utwierdzany w przekonaniu, że wybór produktu Apple oznacza deklarację wartości, przywiązanie do stylu życia i prestiż. Sklep oferował usługę concierge'a i zapewniał indywidualną obsługę. Wystrój miejsca, dobór materiałów takich jak stal nierdzewna, szkło i skandynawskie drewno, był podobnie przejrzysty i perfekcyjny jak same produkty [Ibidem: 194]. 


\section{Kultura organizacyjna}

Dzięki wyeliminowaniu procesu produkcji z własnych struktur i przesunięciu tego zadania na podwykonawców, udało się spółce utrzymać względnie niewielkie zatrudnienie na poziomie 116000 pracowników (dla porównania Walmart zajmujący pierwsze miejsce ${ }^{2}$ na liście Fortune Global $500^{3}$ zatrudniał w 2016 roku 2,3 mln pracowników), co poskutkowało uformowaniem się relatywnie monolitycznej kultury organizacyjnej.

Kultura organizacji jest zawsze w pewnym stopniu unikalna na poziomie organizacji, a po części zależna od otoczenia. W przypadku Apple Inc. nie można badać kultury organizacyjnej tej spółki bez refleksji na temat amerykańskiej kultury, która stanowić będzie punkt odniesienia dla kultury korporacyjnej.

Stany Zjednoczone utrzymują dominującą pozycję w światowej gospodarce od końca wieku XIX. W latach czterdziestych XX wieku USA odpowiadały za ok. $60 \%$ światowej produkcji, w latach pięćdziesiątych za 50\%, w latach siedemdziesiątych udział ten zmalał do $40 \%$. I choć współcześnie kraj ten odpowiada za ok. $20 \%$ produktu światowego ${ }^{4}$ wciąż pozostaje państwem o najwyższym produkcie krajowym brutto [https://encyklopedia.pwn.pl/haslo/Stany-Zjednoczone-Gospodarka;4575385.html (dostęp: 5.06.2018)]. Państwo, którego ludność stanowi około 4,5\% populacji świata, generuje piątą część potencjału gospodarczego naszego globu [https://www.cia.gov/library/publications/the-world-factbook/ (dostęp: 5.06.2018)]. Z tego wynika silny wpływ amerykańskiej kultury (zwłaszcza biznesowej) na resztę świata.

Bjerke zauważa, że Stany Zjednoczone, a w konsekwencji kultura tego kraju, zostały stworzone przez imigrantów i ich potomków, co w konsekwencji czyni ją bardziej złożoną i zróżnicowaną od innych kultur. Dodaje jednak, że amerykańskiej kulturze nadają ton przede wszystkim elementy kultury białych przedstawicieli klasy średniej oraz podkreśla istnienie relatywnie charakterystycznej amerykańskiej kultury biznesu [Bjerke, 2004: 98].

Amerykańską kulturę charakteryzują: zorientowanie na postęp i ciągły wzrost, wysoka tolerancja ryzyka, kult nowoczesności, materializm, ciągła aktywność, gloryfikacja wydajności, uwielbienie indywidualizmu i przywiązanie do wolności [Ibidem: 100, 118].

2 Apple znalazł się na 9. miejscu z przychodem na poziomie 215,639 mld.

3 Co roku publikowany przez magazyn Fortune raport obejmujący 500 spółek osiągających najwyższe przychody na świecie.

4 Dane za 2007 rok. 


\section{Unikanie niepewności}

Amerykanów wychowuje się w duchu wiary w postęp, która wiąże się z pozytywnym podejściem do zmian, a także poglądem, że zmianą można zarządzać. Konsekwencją tej optyki jest skłonność do ryzyka. „Wiąże się z tym aktywna, dynamiczna postawa i gotowość do podejmowania ryzykownych decyzji. Niepewność w życiu jest traktowana jak coś normalnego, a ryzyko ekonomiczne ocenia się przez pryzmat potencjalnych nagród" [Ibidem: 99-100]. Skłonność do ryzyka jest istotnym elementem kultury proinnowacyjnej. Scott Shane zaobserwował, że państwa, których kultura cechuje się wysokim wskaźnikiem unikania niepewności, rejestrują mniej nowych znaków towarowych, uznał je więc za mniej innowacyjne. W opracowaniach G. Hofstede Stany Zjednoczone miały jeden z najniższych na świecie wskaźników unikania niepewności [Hofstede, 2007: 196].

Kultura Apple przejawia zarówno cechy organizacji o silnym jak i słabym unikaniu niepewności. Na poziomie całej organizacji i decyzji podejmowanych przez lidera, spółka wielokrotnie wykazała umiejętność podjęcia ryzyka. Systematycznie jako pierwsza zmieniała standardy, eliminując w swoich produktach elementy uważane za normatywne. $\mathrm{Z}$ drugiej strony ścisła kontrola sprawowana nad każdym aspektem, a także polityka utrzymywania przez pracowników w tajemnicy swojej pracy, są procedurami, które służą zmniejszaniu niepokoju i świadczą o silnym unikaniu niepewności w organizacji.

\section{Orientacja krótkoterminowa i dtugoterminowa}

Amerykańska kultura biznesu zakłada pełną kontrolę nad czasem, który interpretuje się liniowo i który należy możliwie efektywnie wykorzystać. Według A. Trompenaarsa w kulturach o sekwencyjnym podejściu do czasu dominują krótkoterminowe strategie biznesowe [Bjerke, 2004: 101]. Hofstede zaklasyfikował amerykańską kulturę do kultur o orientacji krótkoterminowej, które cechują się według niego wysoką presją na konsumpcję, naciskiem na uzyskiwanie szybkich rezultatów, przywiązaniem do wolności jednostki, wysokim znaczeniem czasu wolnego od pracy oraz merytokracją. Wśród wartości charakterystycznych dla Stanów Zjednoczonych nie pojawiły się oszczędność czy upór [Hofstede, 2007: 224, 236].

Również w tym wymiarze kultura organizacyjna Apple nie jest tożsama amerykańskiej. Należy zwrócić uwagę na fakt, że wizjonerskie przywództwo S. Jobsa wyłamywało się orientacji krótkoterminowej, 
gdyż przedkładało wizerunek organizacji i jej rynkową pozycję w przyszłości nad krótkoterminowymi zyskami i celami. Filozofia pracy nad nowymi produktami wiązała się z nagminnym przekraczaniem terminów. „W przypadku wielu kluczowych przedsięwzięć (...) Jobs naciskał przycisk pauzy w chwili, gdy prace niemal dobiegały końca, po czym decydował się na wprowadzenie gruntownych zmian" [Isaacson, 2011: 597].

\section{Dystans wladzy}

Silną cechą amerykańskiej kultury jest bezpośredniość, występująca wraz z naturalną szczerością i odrzuceniem nadmiernej formalizacji. Zwyczaj wynagradzania przede wszystkim za umiejętności, nie zaś przez wzgląd na staż pracy czy pozycję społeczną, umniejsza znaczenie cech takich jak wiek i miejsce urodzenia [Bjerke, 2004: 104]. Istotna jest także wiara Amerykanów w równość. Występuje ona mimo silnego kultu indywidualizmu i przywiązania do wolności, z którymi niekiedy wchodzi w konflikt. „W Stanach Zjednoczonych nie ma w ogóle uznawanych klas społecznych, głównymi czynnikami różnicującymi są dochód i osiągnięcia, a kultura amerykańska kładzie nacisk na równość w stosunkach społecznych" [Ibidem: 105]. Bjerke zauważa, że w amerykańskiej kulturze „możliwości, standardy oceny, polityka i sposoby postępowania odnoszą się do wszystkich", a zarazem powszechnym podziwem cieszą się indywidualne dokonania. A zatem równość rozumiana jest jako stosowanie takich samych standardów wobec wszystkich, nie zaś jako próba zrównania ich statusu [Ibidem: 106].

Efektem równoległej wiary w równość i indywidualizm, jest średni dystans władzy. Podwładni oczekują od przełożonych, że decyzje zostaną z nimi skonsultowane (charakterystyczne dla kultur o niskim dystansie władzy), ale są gotowi zaakceptować również decyzje autokratyczne (cecha kultur o wysokim dystansie władzy) [Hofstede, 2007: 70]. Wszyscy podlegają temu samemu prawu (niski dystans władzy), ale nie budzą sprzeciwu przywileje dla przełożonych (wysoki dystans władzy).

Tymczasem dystans władzy w Apple jest wybitnie wysoki, o czym świadczy przede wszystkim jej silna centralizacja. Kultura pracy w Apple nie tylko wymagała zatwierdzania przez dyrektora generalnego wszystkich produktów i cech użytkowych, ale wręcz by podwładni oczekiwali bezpośrednich poleceń. Relacje między pracownikami a ich zwierzchnikiem były też silnie nacechowane emocjonalnie co G. Hofstede wskazuje jako cechę kultur o wysokim dystansie władzy. Zauważa również, że w kulturach tych na poziomie państwowym zmiany systemu politycznego 
dokonują się na drodze przewrotów lub rewolucji [Ibidem: 78]. Zarówno odejście S. Jobsa w 1985 roku, jak i jego powrót w 1996 roku odbywały się w atmosferze silnej walki o władzę.

\section{Indywidualizm i kolektywizm}

Ze wskaźnikiem dystansu władzy jest skorelowany inny wyróżniony przez G. Hofstede wymiar - indywidualizm i kolektywizm. Amerykanie mocno wierzą w to, że każdy jest kowalem własnego losu. Modelowym człowiekiem sukcesu, zasługującym na podziw, jest self-made man, czyli osoba która wszystko zawdzięcza wyłącznie własnej pracowitości i talentom. Amerykańska kultura umniejszyła znaczenie klas i statusu przypisanego (przez urodzenie czy wiek), eksponuje zaś status osiągnięty [Bjerke, 2004: 114]. Wpisuje się to we wspomniany już kult indywidualizmu. Bjerke stwierdza, że „gdyby trzeba było wybrać najbardziej charakterystyczną cechę amerykańskiej kultury, to prawdopodobnie zostałby nią indywidualizm" [Ibidem: 111]. Amerykanie uzyskali najwyższy wskaźnik indywidualizmu w analizach Hofstedego, $\mathrm{z}$ tego też powodu $\mathrm{z}$ dużą dozą nieufności podchodzą do kolektywizmu i związanych z nim: socjalizacji i uniformizacji. Wywiera to istotny wpływ na ich podejście do kultury organizacyjnej przedsiębiorstw, w których pracują; mogą jej nie doceniać [Ibidem: 113].

Także w tym obszarze kultura Apple odstaje od amerykańskiej kultury narodowej. Nigdy w spółce nie nagradzano za staż pracy, nie był on również powodem dla okazywania pracownikom nadzwyczajnego respektu. W Apple Inc. można jednak wskazać wiele elementów kolektywistycznego podejścia, z których najważniejszym jest koncentracja na produkcie, nie zaś na pracowniku. Nadrzędnym celem pracy nad projektami w Apple zawsze był wspólny cel, czyli wysokiej jakości urządzenie. Charakterystyczne dla niskiego wskaźnika indywidualizmu jest także brak poszanowania dla czasu wolnego pracowników, skutkujące nagminną pracą $\mathrm{w}$ weekendy i wieczorami. Często nie wynikało to nawet $\mathrm{z}$ bezpośredniego polecenia przełożonego, ale z potrzeb i ambicji pracowników.

Kultura organizacyjna w Apple Inc. jest wyrazista i spójna. Pracownicy spółki nie tylko dobrze znają i rozumieją wartości, jakimi kieruje się spółka, ale również faktycznie się nimi kierują. Skutecznie komunikują tożsamość i atrybuty firmy klientom, tworząc innowacyjny wizerunek organizacji.

Każda firma chce dziś uchodzić za innowacyjną zarówno przez wzgląd na wizerunek marki, jak i realną potrzebę ciągłego projektowania 
przełomowych produktów w realiach nieprzerwanej walki z konkurencją. Sam termin odmienia się przez wszystkie przypadki. Wall Street Journal policzył, że w 2011 roku w sprawozdaniach rocznych i kwartalnych amerykańskich spółek słowo innowacja pojawiło się 33528 razy [Kwoh, 2012]. Powszechnie uważa się, że innowacyjność organizacji można rozwijać poprzez ciągłą stymulację kreatywności pracowników. W epoce silnego przesycenia rynku i krótkich cykli produkcyjnych, sukces przedsiębiorstw determinuje proinnowacyjna kultura organizacyjna [Bieńkowska, 2013: 37].

I choć wielu pracodawców naśladuje to podejście, Apple wychodzi z zupełnie innego założenia. Steve Jobs ustanowił dyscyplinę i kulturę pracy raczej rzadko spotykaną w Dolinie Krzemowej. „Przed powrotem Jobsa Apple znana była z wyjątkowo luźnego podejścia do pracy. Pracownicy przychodzili późno i wychodzili stosunkowo wcześnie. Leniuchowali na zielonym dziedzińcu firmy, grali w zośkę albo bawili się z psami. Lecz Jobs wprowadził nowy rygor i narzucił nowe zasady. Palenie i wprowadzanie psów na teren firmy zostały surowo zabronione, powróciły zaś definiujące załogę Apple cechy - wyczucie branży i żyłka rywalizacji” [Kahney, 2010: 201].

Myślenie o Apple jako pracodawcy nie przywołuje na myśl grup podekscytowanych pracowników rozmawiających o pomyśle na nową aplikację w czasie gry w tenisa stołowego, czy relaksujących się w korporacyjnej siłowni, ale raczej tajne pracownie, których efekty pracy świat poznaje dopiero podczas premiery nowych produktów (a więc dopiero na etapie komercjalizacji innowacji). Apple nie ma też w zwyczaju dzielić się publicznie ani nawet ujawniać swoich innowacji na wczesnym etapie prac (Google od lat pracuje nad autonomicznymi samochodami, wciąż nie pojawiły się jednak na rynku jako finalny produkt). Każda firma chroni swoje wrażliwe dane, patenty i rozwiązania przed ujawnieniem, ale prawdopodobnie żadna nie robi tego tak drobiazgowo jak Apple.

Kultura Apple wykazuje szereg cech, które należy uznać za pozytywne, takich jak tytaniczny nacisk na jakość produktów, przywiązanie do najdrobniejszych detali, czy nieustanne dążenie do prostoty. Pracownicy firmy tworzą produkty których sami z satysfakcją używają. Jednak nie jest to kultura proinnowacyjna. $Z$ racji na aspekt dla firmy najważniejszy - jakość, raczej należy ją określić jako projakościową.

\section{Wnioski z badań}

Apple cieszy się ponadprzeciętną lojalnością klientów, która ma swoje źródło w wizerunku przedsiębiorstwa. Spółka wypracowała 
image innowatora produkującego przełomowe, wysokiej jakości produkty dla świadomych, kreatywnych użytkowników. Siła wizerunku polega na jego wyrazistości. Apple Inc. nie tylko konsekwentnie, w każdym obszarze, komunikuje otoczeniu co jest dla niej najważniejsze, ale także udowadnia, że działania przedsiębiorstwa są zgodne z deklarowanymi wartościami.

Skuteczna komunikacja wizerunku jest możliwa dlatego, że pracownicy Apple świetnie rozumieją tożsamość spółki. Podobnie jak zakup produktu, tak i praca w tej firmie jest deklaracją przekonań i postaw. Taki stan rzeczy implikuje istnienie w spółce wyrazistej, spójnej kultury organizacyjnej, która jednakowoż mocno różni się od kultury symptomatycznej dla Stanów Zjednoczonych. Podczas gdy amerykańską kulturę znamionuje wszechobecny indywidualizm, Apple wykazuje cechy kolektywistyczne. Nacisk w spółce kładzie się przede wszystkim na produkt, nie zaś na pracownika i jego komfort, wolność i ambicje. Apple formułuje długoterminową wizję i dalekosiężne cele. Przedkłada jakość produktu i wizerunek nad terminową realizację cyklu produkcyjnego, podczas gdy Amerykanów jako naród cechuje przede wszystkim gloryfikacja wydajności i nacisk położony na uzyskiwanie szybkich, wymiernych rezultatów. Społeczeństwo amerykańskie przywykło do niepewności i chętnie podejmuje ryzyko, tymczasem Apple pomimo tego, że zatrudnia najlepszych fachowców w swojej branży, nie akceptuje inicjatywy. Konsekwencją tego jest wysoki dystans władzy w spółce. Jako, że kompetencje pracowników są ograniczone, również nie występuje szczególna potrzeba konsultacji. Decyzje podejmuje się autorytarnie. Amerykanie lubią by decyzje były z nimi konsultowane, ale są w stanie zaakceptować autokratyzm, tak długo jak wobec wszystkich stosuje się jednakowe standardy.

Kultura organizacyjna Apple Inc. różni się nie tylko od amerykańskiej kultury narodowej, ale także od kultur korporacyjnych innych firm powszechnie uważanych za innowacyjne. Podczas gdy, np. Google czy $3 \mathrm{M}$ pielęgnują kulturę proinnowacyjną, która pozostawia pracownikom szeroki zakres swobody i szansę wykazania własnej inicjatywy, Apple wykształciło kulturę projakościową, kładąc nacisk na produkt, a decyzyjność pozostawiając $\mathrm{w}$ rękach przełożonych.

Kultura organizacyjna firmy, zwłaszcza autokratyczność, miała swoje źródło w silnym przywództwie założyciela firmy. Steve Jobs był człowiekiem o ogromnych pokładach charyzmy, w skutek czego skutecznie forsował swoje koncepcje. Ograniczał kompetencje swoich podwładnych, nie znosił sprzeciwu i rzadko liczył się z opiniami innych 
ludzi. Był też niezwykle kreatywny i zdawał się doskonale rozumieć potrzeby klientów. Kreował wizję i imputował spółce innowacyjny pierwiastek, skutecznie pozyskując i motywując stronników.

Tym samym Apple Inc. z Jobsem u steru nie wykształciło proinnowacyjnej kultury organizacyjnej, która zakorzeniałaby w firmie metody ciągłego samoistnego kreowania innowacji i pomysłów oraz zachęcałaby pracowników do wychodzenia z inicjatywą. Charyzmatyczne przywództwo Jobsa doprowadziło do tego, że przedsiębiorstwo było innowacyjne tak długo, gdy stał on u jego sterów.

\section{Zakończenie}

Wizerunek jest subiektywną impresją interesariuszy na temat organizacji, a swoje źródło ma przede wszystkim w postrzeganiu organizacji przez samą siebie. Wykreowanie właściwego wizerunku wymaga odkrycia przez członków organizacji jej tożsamości, czyli odkrycia lub sformułowania własnych charyzmatów i określenia, co odróżnia ją od innych organizacji. Tożsamość tak jak kultura organizacyjna opiera się na wartościach. Kultura organizacyjna jest ideologią, która pomaga członkom organizacji interpretować świat w podobny sposób oraz zbiorem wartości, który wskazuje co w przedsiębiorstwie uważa się za właściwe, a co niewłaściwe. Kultura w organizacji jest pochodną kultury narodowej, społeczeństwa świata różnią się od siebie w postrzeganiu i ocenie fundamentalnych zagadnień jak czas, przestrzeń, rzeczywistość, prawda i ludzkie działanie. Kultura korporacyjna implikuje również jak w organizacji sprawuje się władzę. Stosunek do zwierzchności w organizacji determinuje jaki autorament może przyjąć władza.

Przeprowadzone badania wtórne wykazały, że Apple jest jedną z najlepiej postrzeganych marek na świecie, a firma cieszy się dużą lojalnością swoich klientów. Spółka nie tylko pielęgnuje własną tożsamość, ale również zręcznie posługuje się narzędziami marketingowymi, skutecznie komunikując otoczeniu istotne dla niej atrybuty, takie jak innowacja, jakość i elitaryzm. Z wizerunkiem firmy powiązana jest sylwetka Steve'a Jobsa, współzałożyciela i wieloletniego dyrektora generalnego przedsiębiorstwa. W niniejszym rozdziale przybliżono wpływ charakteru i wizjonerstwa Steve'a Jobsa na tenże wizerunek. Charyzma przywódcy skutkowała silnym powiązaniem spółki z jego osobą, z wszystkimi tego konsekwencjami. Jobs doskonale rozumiał jak ważny jest wizerunek i intuicyjnie potrafił go kreować. Dzięki przemożnemu wpływowi na rozwój przedsiębiorstwa, budował tożsamość korporacji opartą na wartościach, którymi sam się kierował. 


\section{BIBLIOGRAFIA}

Altkorn J. (2004), Wizerunek firmy, Wyższa Szkoła Biznesu, Dąbrowa Górnicza.

Bieńkowska J. (2013), Kultura proinnowacyjna - wyzwanie współczesności, „Acta Universitatis Lodziensis. Folia Oeconomica", nr 283, s. 41-54.

Bjerke B. (2004), Kultura a style przywództwa, Oficyna Ekonomiczna, Kraków.

Forbes, The World's Most Valuable Brands, https://www.forbes.com/powerfulbrands/list/ (dostęp: 6.04.2018).

Gallo C. (2011), Steve Jobs. Sekrety innowacji, Wydawnictwo Znak, Kraków.

Griffin R. (2004), Podstawy zarządzania organizacjami, Wydawnictwo Naukowe PWN, Warszawa.

Hernandez R. (2017), Apple has a huge advantage over its rivals ahead of the iPhone 8 release, 18.05.2017, http://markets.businessinsider.com/news/stocks/apple-stockprice-morgan-stanley-note-2017-5-1002022779-1002022779 (dostęp: 6.06.2018).

Hofstede G. (2007), Kultury i organizacje, Polskie Wydawnictwo Ekonomiczne, Warszawa. Isaacson W. (2011), Steve Jobs, Wydawnictwo Insignis, Kraków.

Kahney L. (2010), Być jak Steve Jobs, Wydawnictwo Znak, Kraków.

Kwoh L. (2012), You Call That Innovation?, 23.05.2012, https://www.wsj.com/articles/SB10001424052702304791704577418250902309914 (dostęp: 5.06.2018).

Sikorski C. (2006), Kultura organizacyjna, C.H. Beck, Łódź.

Stogdill R. (1974), Handbook of leadership, Nowy Jork.

Struzik A. (2013), Trickster - definicje, stan badań, rekonesans, „Roczniki Humanistyczne", t. LXI, z. 4, s. 241-251.

Wyniki godne pozazdroszczenia. Ale Apple dopiero idzie na rekord (2017), 3.11.2017, https://businessinsider.com.pl/firmy/strategie/wyniki-finansowe-apple-za-czwartykwartal-i-rok-2017/d319pln (dostęp: 4.05.2018).

Zbiegień-Maciąg L. (2005), Kultura w organizacji. Identyfikacja kultur znanych firm, Warszawa.

https://www.cia.gov/library/publications/the-world-factbook/ (dostęp: 5.06.2018).

https://encyklopedia.pwn.pl/haslo/Stany-Zjednoczone-Gospodarka;4575385.html (dostęp: 5.06.2018).

\section{CULTURAL DETERMINANTS OF CORPORATE IMAGE ON AN EXAMPLE OF APPLE INC. \\ SUMMARY}

The purpose of the chapter was to analyze the innovative image of Apple Inc. and to show how its creation was influenced by the identity of the organization, corporate culture and leadership of Steve Jobs. The study also describes the differences and similarities between the American national culture and the organizational culture of Apple Inc.

Keywords: organizational culture, corporate culture, leadership, image, Apple Inc. 